\title{
Developmental Changes of Recessive Genes-mediated Cucumber mosaic virus (CMV) Resistance in Peppers (Capsicum annuum L.)
}

\author{
Woong-Ki Min *, Jae-Hwang Ryu, and Su-Hyeon Ahn \\ Breeding Research Station, DongbuFarm Hannong Co., Ltd., Anseong 456-933, Korea
}

\begin{abstract}
Cucumber mosaic virus (CMV) is one of the most important viral diseases in pepper (Capsicum annuum L.), and several genes for resistance were reported in Capsicum spp. In Korea, a single dominant gene that is resistant to CMV Fny and CMV P0 has been used for breeding. Recently, a new strain (CMV P1) was reported that could infect cultivars resistant to both CMV Fny and CMV ${ }_{\mathrm{P} 0}$. Therefore, breeding of more robust CMV-resistant cultivars is required. In this study, we surveyed the inheritance of $\mathrm{CMV}_{\mathrm{P} 1}$ resistance and analyzed the location of the resistance loci. After CMV $\mathrm{P}_{1}$ inoculation of various germplasms and breeding lines, one accession (ICPN18-8) showed no visual symptoms at 15 dpi (days post inoculation) but was susceptible after 45 dpi, and one resistant line (I7339) showed resistance until at $45 \mathrm{dpi}$. The latter line was used for tests of resistance inheritance. A total of $189 \mathrm{~F}_{2}$ plants were examined, with 42 individuals showing resistance at 15 dpi and a phenotype segregation ratio close to 1:3 (resistant:susceptible plants). In a lateral ELISA test at $45 \mathrm{dpi}, 11$ plants showed resistance, and the segregation ratio was changed to $1: 15$. These results indicate that resistance in $C$. annuum 'I7339' is controlled by two different recessive genes; we named these resistance genes ' $c m r 3 E$ ' and ' $c m r 3 L$,' respectively. To locate these two resistant loci in the pepper linkage map, various RAPD, SSR, and STS markers were screened; only nine markers were grouped into one linkage group (LG). Only one RAPD primer (OPAT16) was distantly linked with $c m r 3 E(22.3 \mathrm{cM})$ and $c m r 3 L(20.7 \mathrm{cM})$. To develop more accurate markers for marker-assisted breeding, enriching for molecular markers spanning two loci will be required.
\end{abstract}

Additional key words: linkage group, RAPD

\section{Introduction}

Various plant viruses infect peppers (Capsicum annuum L.) cause inhibition of growth, decrease of fruit quality and death. Cucumber mosaic virus (CMV) is one of the important viral diseases in Korea and worldwide, infecting many different crop species including peppers (Choi et al., 2005; Palukaitis et al., 1992). Besides its importance, no complete resistances were found capable of restriction of CMV replication or long-distance movement in pepper. In some cucurbits, resistance to CMV was controlled by one recessive gene (Kang et al., 2005), tomato and Arabidopsis have single dominant gene for resistance (Stamova and Chetelat, 2000; Takahashi et al., 2001, 2002). Several poly-genes for resistance were reported in Capsicum species including 'Perennial' (Caranta et al., 1997; Chaim et al., 2001; Grube et al., 2000; Lapidot et al., 1997), 'Vania' (Caranta et al., 2002), C. baccatum 'PI439381-1-3' (Suzuki et al., 2003) and C. frutescens 'BG2814-6' (Grube et al., 2000). In Arabidopsis and tomato, single dominant gene $\mathrm{RCY}$ and $\mathrm{Cmr}$ were suggested for resistance (Stamova and Chetelat, 2000; Takahashi et al., 2001, 2002). Up to date, three different steps of inhibition of the virus cycles were reported in distinct resistant Capsicum accessions: restriction of host-cell infection (Caranta

\footnotetext{
*Comesponding author: shakespeare@dongbu.com

※ Received 16 June 2013; Revised 9 January 2014; Accepted 5 February 2014. This research was supported by a grant (code: 710001-07) from the Vegetable Breeding Research Center through R\&D Convergence Center Support Program, Ministry for Food, Agriculture, Forestry and Fisheries, Republic of Korea. CMV inoculums used in this study were kindly provided by Dr. B-C Kang from the Plant Genomics and Breeding Institute, Seoul National University, Korea. Capsicum annuum germplasm ICPN-18-8 was kindly provided by Dr. M.C. Cho from the NHRI (National Horticultural Research Institute), Korea.

(C) 2014 Korean Society for Horticultural Science
} 
et al., 1997), suppression of virus multiplication in the whole plants (Nono-Wondim et al., 1993) and restraint of longdistance movement (Dufour et al., 1989).

In Korea, CMV was reported all province cultivating peppers (Choi et al., 2005). Some commercial cultivars, such as 'Bukang' have been used for the resistance sources to CMV in seed companies. From progeny tests, it was revealed that 'Bukang' have a single dominant gene $\mathrm{Cmr} 1$ resistant to CMV Fny and CMV P0 (Kang et al., 2010). For the single dominant resistant gene, three closely linked molecular markers were developed and applied for breeding. Recently, a new strain CMV P1 was reported, which could infect cultivars resistant to both CMV Fny and CMV Korean (Kang et al., 2010; Lee et al., 2006). Korean pepper breeders have been developed many cultivars resistant to both CMV and Phytophthora root rot for open field cultivation, however occurrence of CMV infected plants did not decreased and strength of resistance to CMV was different in many CMV resistant cultivars in the repeated annual survey. Therefore, breeding of more robust CMV resistant cultivars will be important goal of seed companies. In this study, we surveyed inheritance of $\mathrm{CMV}_{\mathrm{P} 1}$ resistance, and described the development of markers linked to the resistance loci.

\section{Materials and Methods}

\section{Plant Materials and DNA Extraction}

A cayenne-pepper inbred line 'I7339 (I)' was used as a CMV ${ }_{\text {P1 }}$ resistant parent and another inbred line 'E1338 (E)' was used as a susceptible parent, both were obtained from DongbuFarm Hannong (Anseong, Korea). A CMV Fny resistant cultivar 'Bu-hong' (DongbuFarm Hannong, Korea) and one CMV P1 resistant accession ICPN-18-8 (provided from Dr. Myung-Cheorl Cho, National Institute of Horticultural \& Herbal Science, Korea) were included. Yolo Wonder was used as susceptible controls in each inoculation. The $\mathrm{F}_{1}$ hybrid (E1338 $\times$ I7339) was self-pollinated to produce 189 $\mathrm{F}_{2}$ plants, and they were analyzed for both CMV resistance and molecular markers. Total genomic DNA was isolated using the protocol described by Kim and Kim (2005).

\section{Virus Materials and Inoculation}

CMV P1 was provided by Dr. Byoung-Cheorl Kang (Seoul National University, Seoul, Korea). The seedlings were inoculated with $\mathrm{CMV}_{\mathrm{P} 1}$ at two leaves stage. The inoculums were prepared from the infected leaves of Nicotiana benthamiana. One gram of infected leaves was ground with $10 \mathrm{~mL}$ of $0.1 \mathrm{M}$ phosphate buffer $\mathrm{pH} 7.0$ and carborundum \#400
(Junsei Pure Chemical Ind., Japan) and inoculated by rubbing the virus onto the two cotyledons. Control plants were mock-inoculated with $0.1 \mathrm{M}$ phosphate buffer $\mathrm{pH}$ 7.0. After inoculation, the inoculated plants were kept in a growth chamber at $25^{\circ} \mathrm{C}$ and symptoms were observed two times, 15 days and 45 days post inoculation (dpi).

\section{Detection of the Presence of CMV by ELISA}

To test systemic infection, ELISA was used to detect CMV P1 according to the manufacturer's protocol (Agdia, USA). Samples for ELISA test were collected and the upper leaves from inoculated cotyledons at $15 \mathrm{dpi}$ and upmost leaves from top branches at $45 \mathrm{dpi}$, two times. Samples were considered to be positive for the presence of CMV 1 when the absorbance value (405 $\mathrm{nm}$ ) of each sample was greater than the mean of two healthy control 'Yolo Wonder' plants.

\section{RAPD Analysis and Linkage Group Construction}

RAPD analyses were performed on each of DNA from resistant and susceptible bulks and 189 individual plants of $F_{2}$ population. A total of 1,200 random primers from OPA to $\mathrm{OPBH}$ primer sets (Operon Technologies, Alameda, CA) and 800 primers from UBC001 to 800 primer sets (University of British Columbia, Vancouver, BC, Canada) were screened. RAPD reactions were performed as described by Zhang et al. (2000). The genomic DNA of the parent cultivars were screened with simple sequence repeat (SSR) and sequence tagged sites (STS) markers (Lee et al., 2009; Mimura et al., 2012; Minamiyama et al., 2006). RAPD and other marker genotyping data were analyzed using CarthaGene software (Schiex and Gaspin., 1997).

\section{Results and Discussion}

\section{Resistance Responses to $\mathrm{CMV}_{\mathrm{P} 1}$ of $C$. annuum}

Cucumber mosaic virus is a major viral disease in Korea, their sequence variations, virulence and survey of resistant germplasm were rarely studied. A new strain CMV ${ }_{\text {P1 }}$ infecting resistant cultivars to $\mathrm{CMV}$ Fny and $\mathrm{CMV}_{\mathrm{P} 0}$ was reported, and belonged to subgroup IB different to CMV Fny (subgroup IA) from movement protein (MP) and coat protein (CP) sequence analysis (Lee et al., 2006).

From CMV ${ }_{\mathrm{P} 1}$ inoculation, all of inoculated 'Yolo Wonder' plants were susceptible to $\mathrm{CMV}_{\mathrm{P} 1}$ strain, indicated that the CMV ${ }_{\mathrm{P} 1}$ screening method is reliable and consistent. Both vein clearing mosaic and leaf distortion symptoms were observed at $15 \mathrm{dpi}$ and expanded to systemically. 
One accession of CMV P1 resistant accession ICPN18-8 showed no visual symptoms at $15 \mathrm{dpi}$, only detected by ELISA test, finally showed delayed symptoms after 45 dpi. All 'Bu-hong' plants were susceptible to the CMV P1 strain, indicated that the CMV ${ }_{\mathrm{P} 1}$ strain can overcome the CMV resistance in 'Bu-hong' plants. CMV P1 symptoms were appeared on the leaves of 'E1338' plants at $15 \mathrm{dpi}$, but no visible symptoms were observed in 'I7339' plants. The result of ELISA test, CMV was detected only in the upper leaves of 'E1338' plants, not in the upper leaves of 'I7339' plants at $15 \mathrm{dpi}$ (Table 1).

Times for virus resistance test of plant breeding materials will be different for each virus types, but usually started at cotyledon stages or one pair of true leaves completed 15 to $20 \mathrm{dpi}$.

Changes in resistance through growth stages of host plant had been rarely reported. In C. annuum, Tobacco Mosaic Virus (TMV)-induced gene (CaTin2) encodes a mature 23 $\mathrm{kDa}$ protein that shares little sequence similarity with other cell wall proteins, fluorescently-tagged CaTin2 appeared to localize and in common with other cell wall proteins (Shin et al., 2003). CaTin2 was usually expressed in leaves and roots, constitutive expression of CaTin2 in transgenic tobacco resulted in some resistance against TMV or CMV, between 7 and $14 \mathrm{dpi}$ after inoculation, but the resistance was lost one month after inoculation, the expression of the CaTin2 cell wall protein probably restricted virus movement and accumulation (Shin et al., 2003).

\section{Inheritance of Resistance to $\mathrm{CMV}_{\mathrm{P} 1}$ Strain in $C$. annuum 'I7339'}

In the $F_{2}$ population, a total of 189 plants were examined for CMV ${ }_{1} 1$ resistance in two times, first at $15 \mathrm{dpi}$ and second at 45 dpi. Of these, 42 individuals showed resistance, 147 plants showed susceptible from ELISA test at the first test (15 dpi). The phenotype segregation ratio was closed to the 1:3 ratio (resistance : susceptible plants), indicating single recessive gene inheritance pattern $\left(\chi^{2}=0.002, P\right.$ $=0.967)$. In the lateral ELISA test at $45 \mathrm{dpi}, 11$ plants showed resistance, 178 plants showed susceptible, the phenotype segregation ratio was close to the 1:15 (resistance: susceptibility) $\left(\chi^{2}=0.060, P=0.807\right)$ (Table 1$)$. A total of 31 resistant plants at $15 \mathrm{dpi}$ became susceptible at 45 dpi. These results indicated that the resistance in $C$. annuum 'I7339' is controlled by two different genes with a recessive manner. We named these resistance genes ' $c m r 3 E$ ' and 'cmr3L' respectively.

Studies for the resistance to CMV in C. annuum have been reported many research groups, most of them were incomplete dominant and quantitatively inherited (Caranta et al., 1997, 2002; Grube et al., 2000), except for $\mathrm{Cmr} 1$ (Kang et al., 2010). Cmr1 on the LG2 is the only dominant resistance gene known in pepper, but resistance is broken down by $\mathrm{CMV}_{\mathrm{P} 1}$ strain, requiring more robust CMV resistant germplasm (Kang et al., 2010). Recently, single recessive gene 'cmr2' resistant to CMV ${ }_{\mathrm{P} 1}$ was reported in pepper, located on chromosome 1 (Park et al., 2011). The resistance was controlled at the level of virus replication, different to 'Cmr1' which involves inhibition of the systemic movement of CMV (Kang et al., 2010).

In this study, virus infection was tested two times, 15 dpi and 45 dpi. Firstly, 47 plants showed no visible symptoms and negative in ELISA test at 15 dpi, 36 individuals become susceptible at $45 \mathrm{dpi}$. These results indicated that two different mechanisms might be involved for the resistance to $\mathrm{CMV} \mathrm{P}_{1}$ - one gene for suppression in cellular level of

Table 1. Resistance responses and segregation analysis of $C$. anuum to CMV P1 strain.

\begin{tabular}{|c|c|c|c|c|c|c|c|}
\hline \multirow{3}{*}{ Population } & \multirow{2}{*}{\multicolumn{2}{|c|}{ Observed ratio (R:S) }} & \multirow{2}{*}{\multicolumn{2}{|c|}{$\chi^{2}(\mathrm{P})$}} & \multicolumn{3}{|c|}{ ELISA (Absorbance $405 \mathrm{~nm}$ ) } \\
\hline & & & & & \multirow{2}{*}{ Non-inoculated } & \multicolumn{2}{|c|}{ Inoculated } \\
\hline & $15 \mathrm{dpi}$ & $45 \mathrm{dpi}$ & 15 dpi & $45 \mathrm{dpi}$ & & $15 \mathrm{dpi}^{\mathrm{z}}$ & $45 \mathrm{dpi}$ \\
\hline ICPN-18-8 & $0: 10$ & $0: 10$ & - & - & - & 0.673 & 1.581 \\
\hline I7339 & $17: 0$ & $17: 0$ & - & - & 0.217 & 0.246 & 0.289 \\
\hline EI $F_{1}$ & $0: 15$ & $0: 15$ & - & - & - & 0.636 & 1.623 \\
\hline $\mathrm{EI} \mathrm{F}_{2}$ & $47: 142$ & $11: 178$ & $\begin{array}{c}0.002 \\
(0.967)\end{array}$ & $\begin{array}{c}0.060 \\
(0.807)\end{array}$ & - & - & - \\
\hline
\end{tabular}

\footnotetext{
${ }^{\mathrm{z}}$ Days post inoculation.
} 


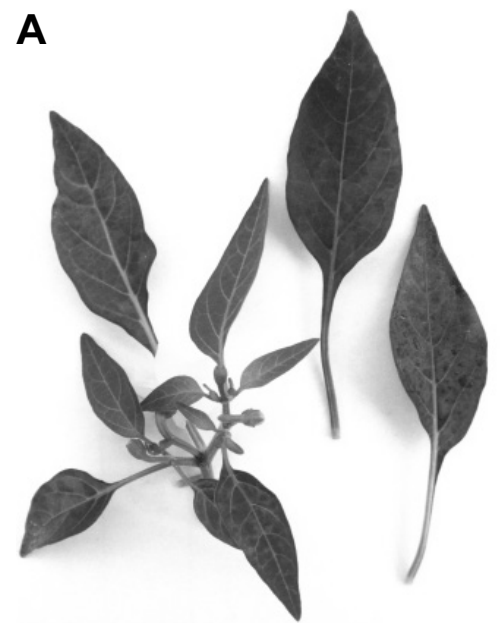

B

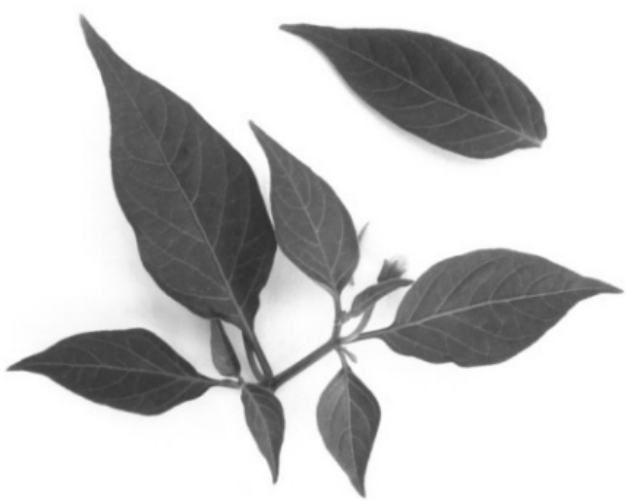

Fig. 1. Phenotypic differences of CMV ${ }_{\mathrm{P} 1}$ strain in susceptible plant ICPN-18-8 (A) and resistance plant 'I7339' (B) at 45 days after inoculation. Susceptible plant showed vein clearing mosaic and leaf distortion symptoms.

virus replication ( $\mathrm{cmr} 3 E$ ), the other for inhibition of long distance movement of CMV (cmr3L). Because CMV inoculated plants of EI $\mathrm{F}_{2}$ population were transplanted to vinyl greenhouse at $30 \mathrm{dpi}$, gene for suppressing CMV replication ( $c m r 3 E$ ) could be affected by environmental conditions such as high temperature.

\section{Linkage Analysis of the $\mathrm{CMV}_{\mathrm{P} 1}$ Resistance Loci}

To locate $c m r 3 E$ and $c m r 3 L$ loci in pepper linkage map, total 2,000 RAPD primers, 115 SSR markers and 37 STS markers were screened using two parental lines, then polymorphic markers were test in the resistant and susceptible bulks of $\mathrm{EI} \mathrm{F}_{2}$ population, only 9 primers were showed polymorphisms between bulked plants and mapped (3.6\%). Because two parents of $\mathrm{EI} \mathrm{F}_{2}$ population were breeding lines they shared low polymorphisms compared to wild types. One linkage group was constructed containing 9 markers (Fig. 2). It shared one common marker (CAMS352-2) with LG4 in the map of Minamiyama et al. (2006), other SSR markers were monomorphic between parents used int this study. Only one RAPD primer OPAT16 (5'-CTCTCCGTAG-3') was distantly linked with $\mathrm{cmr} 3 E(22.3 \mathrm{cM})$ and $\mathrm{cmr} 3 \mathrm{~L}(20.7$ cM). Two loci for resistance to CMV $\mathrm{P1}$ were located on the LG4 in this study, different to the $\mathrm{cmr} 2$ on chromosome 1 in previous study (Park et al., 2011), due to differ in genetic resources. Therefore, it is supposed that the gene required for inhibition of the systemic movement of CMV are absent in 36 plants, resulting in susceptibility. In the RNA3 sequence analysis for P0 resistant-breaking isolate (Ca-P1-CMV), the same CMV isolate used in this study, revealed Ca-P1-CMV belongs to CMV subgroup IB whereas
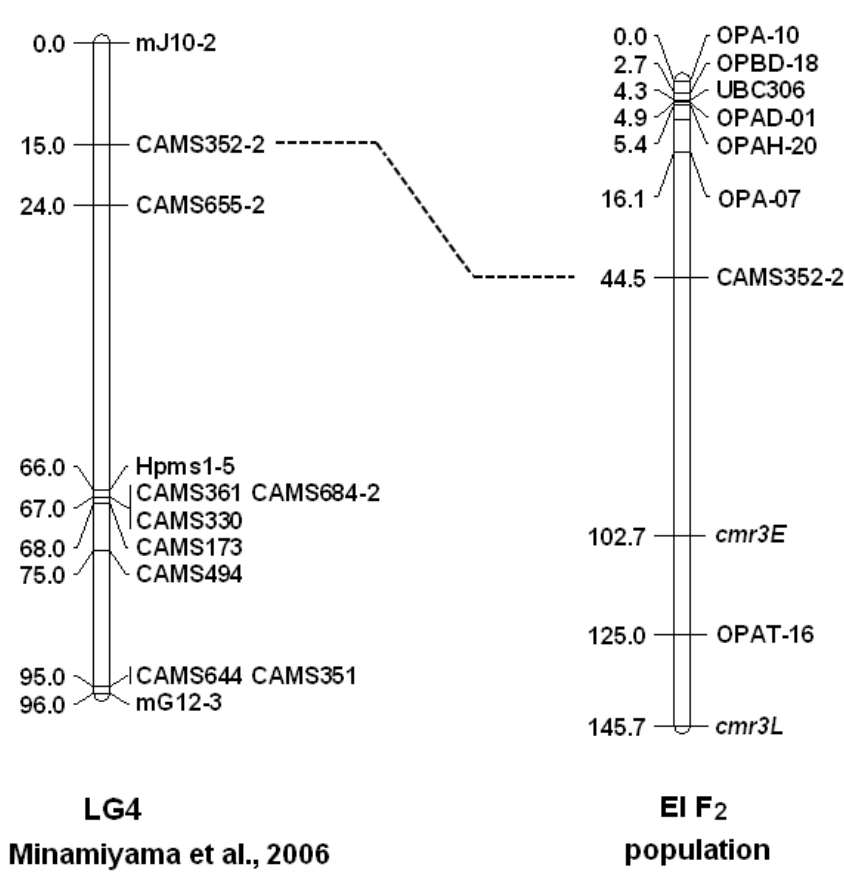

Minamiyama et al., 2006

Fig. 2. The linkage map showing genetic distances of the pepper $\mathrm{CMV}_{\mathrm{P} 1}$ resistance loci and molecular markers from EI $\mathrm{F}_{2}$ population compared with LG4 in Minamiyama et al. (2006). Markers on the LG4 are partially shown here. One common marker CAMS352-2 was mapped in EI $F_{2}$ map. The marker names and distances (Kosambi, cM) are presented on the right and left sides of the central bar, dotted line indicate common marker.

the ordinary strain (Fny-CMV) group to subgroup IA from movement protein (MP) and coat protein (CP) comparison (Lee et al., 2006). They also suggested the possibility of 


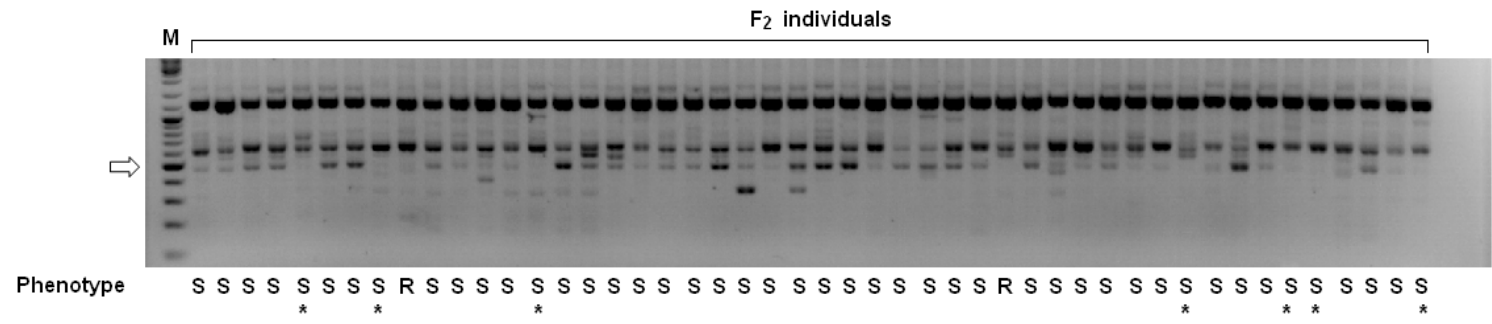

Fig. 3. Amplification pattern of part of individuals from EI $F_{2}$ population with OPAT-16. $M$ 1kb plus ladder. Arrow indicates susceptible plant specific band, star-marks denote individuals showed inconsistent results when compared phenotype and marker result.

changes in the MP and CP sequences resulting in different responses between pepper and virus. Similar response was found in the 'Bu-hong' cultivar (resistant to CMV Fny), it showed susceptible symptoms after inoculated with CMV $\mathrm{P1}$. Further research remains for the comparison of genes for resistance to different $\mathrm{CMV}$ isolates in different pepper germplasms.

One distantly linked marker OPAT16 is insufficient for marker assisted selection of breeding lines or germplasms, requiring more closely linked markers. To narrow down and delimit loci, AFLP analysis and diverse approaches using pepper genome sequences being performed, further experiments will be needed to clarify genetic and inheritance of genes for resistance to diverse CMV strains including CMV 1 1.

\section{Literature Cited}

Caranta, C., A. Palloix, V. Lefebvre, and A.M. Daubèze. 1997. QTLs for a component of partial resistance to cucumber mosaic virus in pepper: restriction of virus installation in host-cells. Theor. Appl. Genet. 94:431-438.

Caranta, C., S. Pfliege, V. Lefebvre, A.M. Daubeze, A. Thabuis, and A. Palloix. 2002. QTLs involved in the restriction of Cucumber mosaic virus (CMV) long-distance movement in pepper. Theor. Appl. Genet. 104:586-591.

Chaim, A.B., R.C. Grube, M. Lapidot, M. Jahn, and I. Paran. 2001. Identification of quantitative trait loci associated with resistance to Cucumber mosaic virus in Capsicum annuum. Theor. Appl. Genet. 102:1213-1220.

Choi, G.S., J.H. Kim, D.H. Lee, J.S. Kim, and K.H. Ryu. 2005. Occurrence and distribution of viruses infecting pepper in Korea. Plant Pathol. J. 21:258-261.

Dufour, O., A. Palloix, K. Gebre-Selassie, E. Pochard, and G. Marchoux. 1989. The distribution of cucumber mosaic virus in resistant and susceptible plants of pepper. Can. J. Bot. 67: 655-660.

Grube, R.C., Y. Zhang, J.F. Murphy, F. Loaiza-Figueroa, V.K. Lackney, R. Provvidenti, and M. Jahn. 2000. New source of resistance to Cucumber mosaic virus in Capsicum frutescens. Plant Dis. 84:885-8981.

Kang, B.C., I. Yeam, and M. Jahn. 2005. Genetics of plant virus resistance. Annu. Rev. Phytopathol. 43:581-621.

Kang, W.-H., N.H. Hoang, H.-B. Yang, J.-K. Kwon, S.-H. Jo, J.-K. Seo, K.-H. Kim, D. Choi, and B.-C. Kang. 2010. Molecular mapping and characterization of a single dominant gene controlling CMV resistance in peppers (Capsicum annuum L.). Theor. Appl. Genet. 120:1587-1596.

Kim, D.H. and B.D. Kim. 2005. Development of SCAR markers for early identification of cytoplasmic male sterility genotype in chili pepper (Capsicum annuum L.). Mol. Cells 20:416-422.

Lapidot, M., I. Paran, R. Ben-Joseph, S. Ben-Harush, M. Pilowsky, S. Cohen, and C. Shifris. 1997. Tolerance to Cucumber mosaic virus in pepper: Development of advanced breeding lines and evaluation of virus level. Plant Dis. 81:185-188.

Lee, H.R., I.H. Bae, S.W. Park, H.J. Kim, W.K. Min, J.H. Han, K.T. Kim, and B.D. Kim. 2009. Construction of an integrated pepper map using RFLP, SSR, CAPS, AFLP, WRKY, rRAMP and BAC end sequences. Mol. Cells 27:21-37.

Lee, M.Y., J.H. Lee, H.I Ahn, J.Y. Yoon, N.H. Her, J.K. Choi, G.S. Choi, D.S. Kim, C.H. Harn, and K.H. Ryu. 2006. Identification and sequence analysis of RNA3 of a resistance-breaking Cucumber mosaic virus isolate on Capsicum annuum. Plant Pathol. J. 22:265-270.

Mimura, Y., T. Inoue, Y. Minamiyama, and N. Kubo. 2012. An SSR-based genetic map of pepper (Capsicum annum L.) serves as an anchor for the alignment of major pepper maps. Breeding Sci. 62:93-98.

Minamiyama, Y., M. Tsuro, and M. Hirai. 2006. An SSR-based linkage map of Capsicum annuum. Mol. Breeding 18:157-169.

Nono-Wondim, R., K. Gebre-Selassie, A. Palloix, E. Pochard, and G. Marchoux. 1993. Study of multiplication of Cucumber mosaic virus in susceptible and resistant Capsicum annuum lines. Ann. Appl. Biol. 122:49-56.

Palukaitis, P., M.J. Roossinck, R.G. Dietzgen, and R.I.B. Francki. 1992. Cucumber mosaic virus. Adv. Virus Res. 41:281-341.

Park, S.-W., N.H. Hoang, W.-H. Kang, M. Schrieck, H.-R. Lee, D. Choi, and B.-C. Kang. 2011. Development of molecular markers for a single recessive resistance gene against $\mathrm{CMV}$ 
in pepper (Capsicum annuum L.). In: International symposium commemorating the $20^{\text {th }}$ anniversary of Korea Capsicum research cooperative: Pepper disease and resistance breeding. Chungbuk National University, Cheongju, Korea, p. 502.

Schiex, T. and C. Gaspin. 1997. CARTHAGENE: Constructing and joining maximum likelihood genetic map. In: Fifth international conference on intelligent systems for Molecular Biology, Porto Carras, Halkidiki, Greece, p. 258-267.

Shin, R., C.J. Park, J.M. An, and K.H. Paek. 2003. A novel TMV induced hot pepper cell wall protein gene (CaTin2) is associated with virus-specific hypersensitive response pathway. Plant Mol. Biol. 51:687-701.

Stamova, B.S. and R.T Chetelat. 2000. Inheritance and genetic mapping of Cucumber mosaic virus resistance introgresed from Lycopersicon chilense into tomato. Theor. Appl. Genet. 101:527-537.

Suzuki, K., T. Kuroda, Y. Miura, and J. Muria. 2003. Screening and field traits of virus resistant source in Capsicum spp. Plant Dis. 87:779-783.

Takahashi, H., M. Suzuki, K. Natsuaki, T. Shigyo, K. Hino, T. Teraoka, D. Hosokawa, and Y. Ehara. 2001. Mapping the virus and host genes involved in the resistance response in Cucumber mosaic virus-infected Arabidopsis thaliana. Plant Cell Physiol. 42:340-347.

Takahashi, H., J. Hiller, Y. Nozaki, M. Takeda, J. Shah, S. Hase, M. Ikegami, Y. Ehara, and S.P. Dinesh-Kumar. 2002. RCY1, and Arabidopsis thaliana RPP8/HRT family resistance gene, conferring resistance to Cucumber mosaic virus requires salicylic acid, ethylene and a novel signal transduction mechanism. Plant J. 32:655-667.

Zhang, B., S. Huang, G. Yang, and J. Guo. 2000. Two RAPD markers linked to a major fertility restorer gene in pepper. Euphytica 113:155-161. 